\title{
Chemical modification of the surface of alumina with alkaline earth metal oxides using the polymeric precursor method for catalysis application
}

\section{(Modificação química da superfície de alumina com óxidos de metais alcalino-terrosos usando o método do precursor polimérico para aplicação em catálise)}

\author{
A. P. Maciel', M. H. A. Tavares ${ }^{1}$, R. S. Melo', F. C. Silva ${ }^{1}$, L. E. B. Soledade', \\ C. J. Dalmaschio ${ }^{3}$, E. R. Leite L. Longo $^{4}$ \\ ${ }^{1}$ Departamento de Química, Universidade Federal do Maranhão - UFMA, Av. Portugueses 1966, Bacanga, \\ S. Luís, MA, Brazil 65080-805 \\ ${ }^{2}$ Universidade Federal do Maranhão - UFMA, Campus Universitário de Pinheiro, Estrada de Pacas $\mathrm{km} \mathrm{10,}$ \\ Enseada, Pinheiro, MA, Brazil 65200-000 \\ ${ }^{3}$ Departamento de Química, Universidade Federal de S. Carlos - UFSCar, \\ Via Washington Luiz, km 235, S. Carlos, SP Brazil 13565-905 \\ ${ }^{4}$ Instituto de Química, Universidade Estadual Paulista - UNESP, Rua Prof. Francisco Degni, s/n, Quitandinha, \\ Araraquara, SP Brazil 14801-970 \\ adeilton@pq.cnpq.br
}

\begin{abstract}
In this study, modifications of alumina surface with of alkaline earth metal oxides were studied, using the polymeric precursor method. The modified compounds were characterized by X-ray diffraction, nitrogen adsorption-desorption and scanning electron microscopy. The catalytical properties of these new catalysts were evaluated for the transesterification reaction of babassu oil. It is observed that the transesterification reaction of babassu oil with methanol was successfully carried out using the modified alumina samples.
\end{abstract}

Keywords: surface modification, alumina, alkaline earth metal oxides.

\section{Resumo}

Neste trabalho foram estudadas modificações da superficie de alumina com óxidos de metais alcalino-terrosos, usando o método dos precursores poliméricos. Os compostos modificados foram caracterizados por difração de raios $X$, adsorção-dessorção de nitrogênio e microscopia eletrônica de varredura. As propriedades catalíticas desses novos catalisadores foram avaliadas para a reação de transesterificação de óleo de babaçu. Foi observado que a reação de transesterificação de óleo de babaçu com metanol ocorreu com sucesso na presença das aluminas modificadas.

Palavras-chave: modificação de superfície, alumina, óxidos de metais alcalino-terrosos.

\section{INTRODUCTION}

Nowadays, many studies have been undertaken aiming at obtaining new solid-state materials displaying physical and chemical properties that are suitable for useful technological applications. It is well known that alumina is one of these materials, once unmodified and modified alumina have been studied for various applications.

The Bayer process, starting from bauxite, is the most common route for the production of alumina. However, there are several methods for preparing this material. For example, Ibrahim and Abu-Ayana [1] used the sol-gel polymeric route for synthesizing ultrathin alumina. Recently, alumina has been applied as soft replica molding for large area UVnanoinprint lithography [2] and nitric oxide sensors [3]. Among many other applications, it can be used as substrate for superconducting materials [4], packing material for the reversed-stationary phase of HPLC columns [5] support for various active phases [6-8], in heterogeneous catalysis. Chen and co-workers [9] prepared a series of alumina-supported alkaline earth metal oxides by impregnation and studied the basicities of these materials by temperature-programmed desorption of carbon dioxide. However, the surface of solids can be modified by using other physical and chemical 
techniques. Maciel and co-workers $[10,11]$ modified the surface of alumina with lanthanum oxide nanocoats, using the polymeric precursor method, a sol-gel like method. In this study, the authors coated the water-dispersed alumina particles, with a polymeric precursor. The modified alumina shows, at high temperatures, significant modifications in the grain morphology and microstructure.

Thus, in the present work we report the results on the investigation of surface modifications of commercial alumina with alkaline earth metals, using the polymeric precursor method and we report results on the catalytic activity of these materials. The catalytic properties of new materials were appraised for biodiesel from the transesterification reaction of the babassu oil into methanol. Babassu oil is obtained from the seeds of the babassu tree (native Brazilian palm) that contains a high percentage of saturated fatty acids.

\section{MATERIALS AND METHODS}

The samples of commercial alumina with the surface modified by alkaline earth metal oxides were prepared using the following starting materials: barium nitrate (Aldrich, purity $>99.9 \%$ ), calcium nitrate (CQA, purity $>99.5 \%$ ), magnesium nitrate (CQA, purity $>99.5 \%$ ), commercial alumina (ALUMAR, Brazil, purity $>99 \%$ ), citric acid (Merck, purity $>99.9 \%$ ) and ethylene glycol (Mallinckrodt Baker, purity $>99.9 \%$ ).

Polymeric precursors from alkaline earth metal oxides were used to modify the alumina surface. These precursors

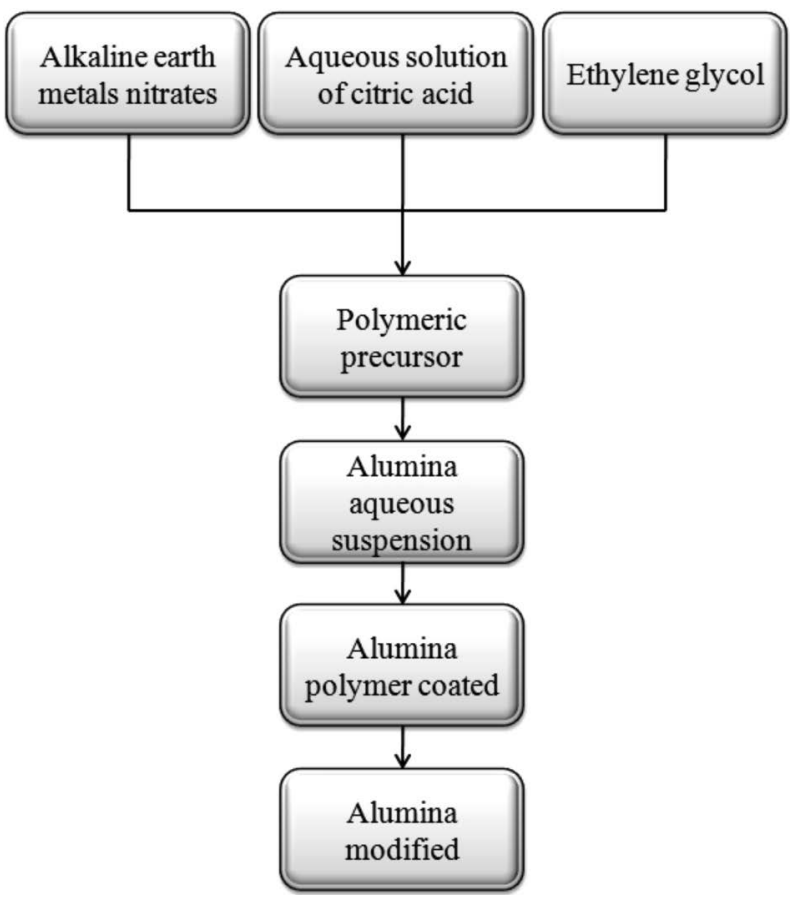

Figure 1: The main steps for preparing alumina modified with alkaline earth metal oxides by the polymeric precursor method.

[Figura 1: Principais etapas para preparação da alumina modificada com óxidos de metais alcalino-terrosos pelo método dos precursores poliméricos.] were obtained from alkaline earth metal nitrates and citric acid. Ethylene glycol was added to promote the polymerization reaction. The aqueous solutions of such polymeric precursor method were prepared with appropriate reagents in distilled water. These polymeric precursors were added to the alumina aqueous suspension, previously dispersed in distillated water, using an ultra-sonic probe [11]. Adequate amounts of polymeric precursors of alkaline earth metal oxides were added in order to achieve exactly $5 \%$ molar concentrations of the different alkaline earth metals in relation to alumina. Following, water was slowly evaporated at $80^{\circ} \mathrm{C}$. The dried materials were decomposed for $4 \mathrm{~h}$ at $350^{\circ} \mathrm{C}$ to remove the organic matter. Finally, these materials were heat treated for $2 \mathrm{~h}$ at $700{ }^{\circ} \mathrm{C}$. Fig. 1 displays the main steps required for preparing commercial alumina modified with alkaline earth metal oxides by the polymeric precursor method.

The materials were structurally characterized by X-ray diffraction (XRD) using a Rigaku-DMax/2500PC, Japan, diffractometer with Cuk $\alpha$ radiation $(\lambda=1.5406 \AA)$ in the $2 \theta$ range from $20^{\circ}$ to $75^{\circ}$, with angular step $0.05^{\circ} / \mathrm{s}$.

The BET and BJH methods were applied for the determination of the specific surface area, and porous structure, respectively. The nitrogen adsorption-desorption isotherms were measured by means of a Micromeritics ASAP 2000 system at $-196{ }^{\circ} \mathrm{C}$. Before the measurement, the samples were dried at $100{ }^{\circ} \mathrm{C}$ and evacuated until that a degassing pressure lower than $6 \mu \mathrm{mHg}$ was attained.

The sample morphologies were verified using scanning electron microscopy (FEG-SEM), Carl Zeiss Supra 35-VP. All measurements were performed at room temperature.

Semi-refined babassu oil, obtained from Empresa Oleaginosas do Maranhão (OLEAMA, S. Luís, MA, Brazil) and methanol (Quimex, PA) were utilized. These reagents were used as received.

The transesterification reactions were carried out in a Parr reactor series 4561 with Parr 4842 controller. The reactions occurred at $180{ }^{\circ} \mathrm{C}$ for $16 \mathrm{~h}$. The babassu methyl esters obtained were analyzed by gas chromatography (GC) in a Varian 3800 Chromatograph with a flame ionization detector and 5\% phenyl $95 \%$ polydimethylsiloxane column $(30 \mathrm{~m} \times 0.25 \mathrm{~mm})$. The temperatures of the injector and detector were set at 290 and $300{ }^{\circ} \mathrm{C}$, respectively.

\section{RESULTS AND DISCUSSION}

Fig. 2 displays the obtained X-ray diffraction patterns for commercial alumina, (a) unmodified, (b) modified with 5\% calcium oxide and (c) modified with 5\% magnesium oxide. The XRD pattern for alumina modified with $5 \%$ barium is shown in Fig. 3.

In Fig. 2, the XRD patterns of unmodified alumina and alumina modified with calcium and magnesium oxides only display two characteristic phases: corundum (rhombohedral) and aluminum oxide (monoclinic), according to the corresponding JCPDS files 46-1212 and 23-1009, respectively. 


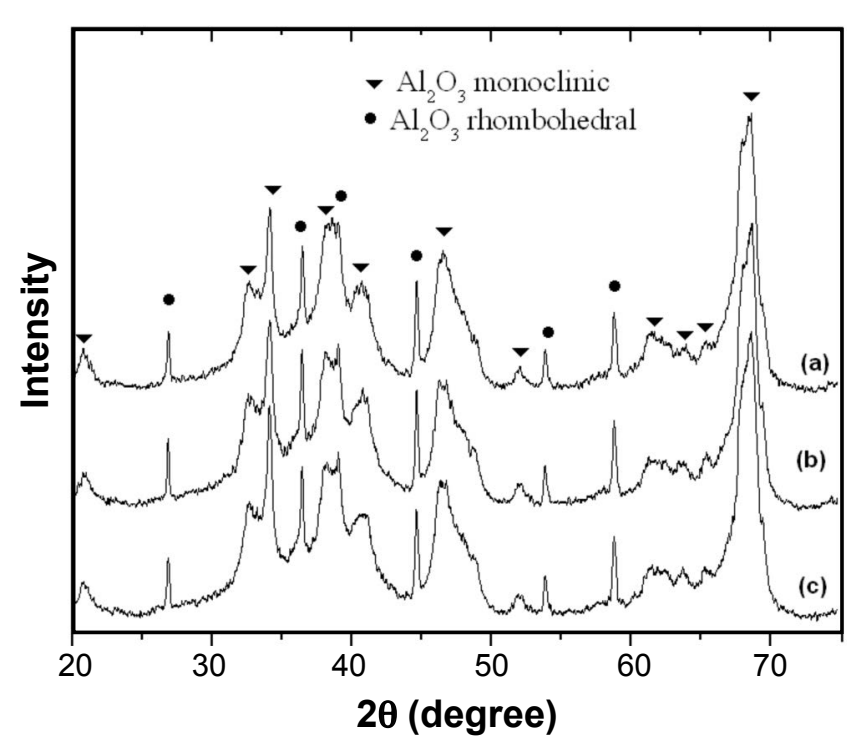

Figure 2: XRD patterns, (a) for unmodified alumina, (b) for alumina modified with $5 \%$ calcium oxide and (c) for alumina modified with $5 \%$ magnesium oxide.

[Figura 2: Padrões de DRX, (a) para alumina não modificada, (b) para alumina modificada com $5 \%$ de óxido de cálcio e (c) para alumina modificada com 5\% de óxido de magnésio.]

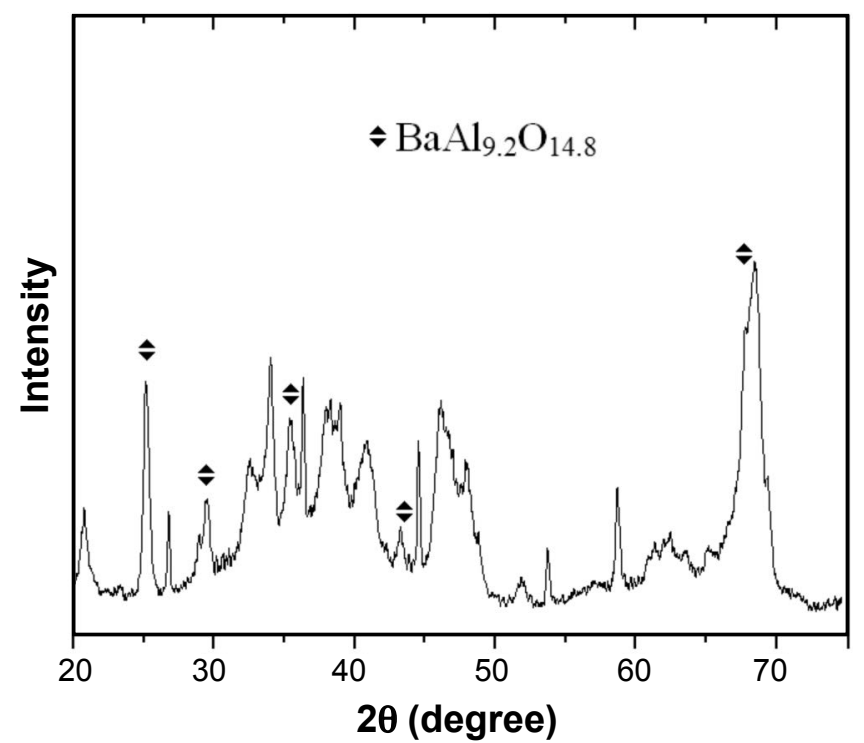

Figure 3: XRD pattern for alumina modified with $5 \%$ barium oxide. [Figura 3: Padrão de DRX para alumina modificada com 5\% de óxido de bário.]

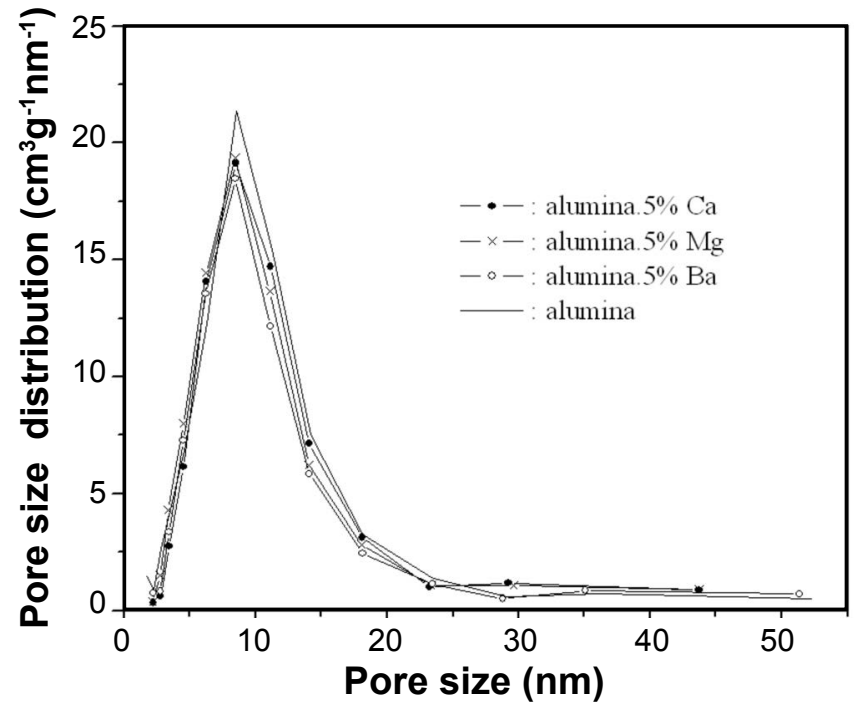

Figure 4: Information on the pore structure of the unmodified and modified alumina samples heat treated at $700{ }^{\circ} \mathrm{C}$. (a) $\mathrm{N}_{2}$ adsorptiondesorption isotherms and (b) pore size distributions.

[Figura 4: Informações sobre a estrutura de poros de amostras de alumina não modificada e modificadas tratadas termicamente a $700{ }^{\circ} \mathrm{C}$. (a) Isotermas de adsorção-dessorção de $\mathrm{N}_{2}$ e (b) distribuição de tamanho de poros.]

However, for the sample modified with barium oxide, occurs the formation of a new crystalline phase, see Fig. 3. It is observed that, in this case, the new structure obtained on the surface of the commercial alumina modified by barium oxide, using the sol-gel method, is related to the stoichiometry $\mathrm{BaAl}_{9.2} \mathrm{O}_{14.8}$ (JCPDS file 33-0129). A large number of nonstoichiometric barium aluminates are known, in which the phase formation is related to the molar ratio between barium oxide and alumina [12-14]. Nevertheless, $\mathrm{BaAl}_{92} \mathrm{O}_{148}$ is not a common aluminate phase. The formation of $\mathrm{BaAl}_{92} \mathrm{O}_{148}$ can be justified by the new route synthesis, in which, initially the barium polymeric precursor is attached on the alumina surface. Subsequently the material undergoes a heat treatment. The alumina surface atoms easily react with barium oxide giving rise to the aluminate phase on surface of the alumina. The X-ray patterns for unmodified alumina and alumina modified with barium oxide are very similar, except that the latter presents the peaks of the new phase. This similarity indicates that the bulk alumina support is not modified in the process. This suggests that only the surface

Table I - Textural properties of the unmodified alumina and alumina modified with $\mathrm{Ba}, \mathrm{Ca}, \mathrm{Mg}$. [Tabela I - Propriedades texturais da alumina não modificada e modificadas com Ba, Ca, Mg.]

\begin{tabular}{lcccc}
\hline Parameter & Sample 1 & Sample 2 & Sample 3 & Sample 4 \\
\hline BET surface area, $\mathrm{m}^{2} / \mathrm{g}$ & 58.20 & 45.20 & 49.32 & 48.25 \\
BJH surface area of pores, $\mathrm{m}^{2} / \mathrm{g}$ & 85.46 & 67.85 & 71.05 & 73.65 \\
Micropore area, $\mathrm{m}^{2} / \mathrm{g}$ & -5.22 & -3.07 & -0.56 & -1.78 \\
Micropore Volume, $\mathrm{cm}^{3} / \mathrm{g}$ & -0.0034 & -0.0023 & -0.0010 & -0.0016 \\
Average pore diameter $(\mathrm{BJH}), \mathrm{nm}$ & 9.14 & 9.69 & 9.96 & 9.42 \\
\hline
\end{tabular}

Sample 1: Unmodified alumina; Sample 2: Alumina. $5 \%$ Ba; Sample 3: Alumina.5\% Ca; Sample 4: Alumina.5\% Mg 

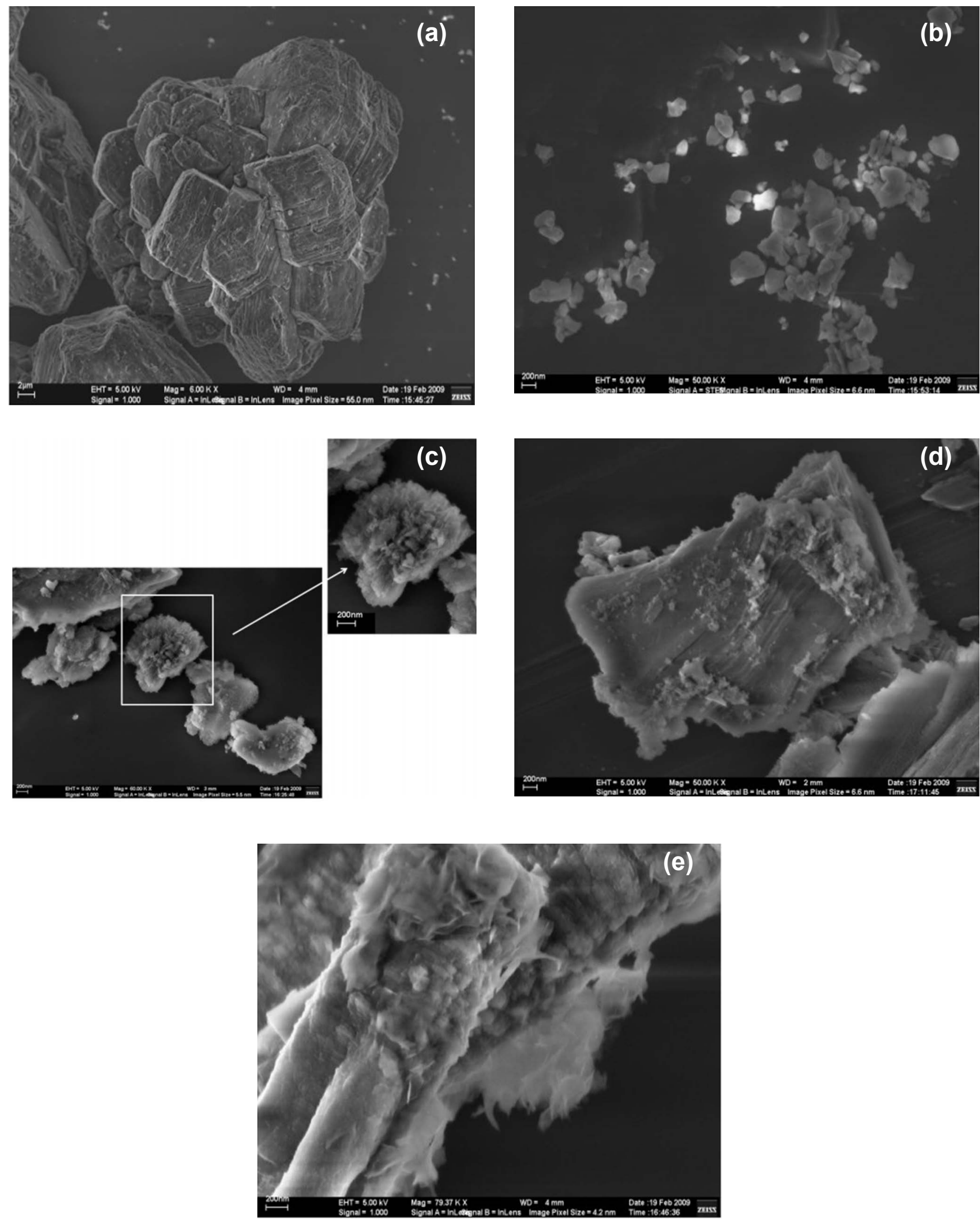

Figure 5: SEM micrographs. (a, b) unmodified alumina, (c) alumina modified with 5\% barium oxide (d) alumina modified with 5\% calcium and (e) alumina modified with $5 \%$ magnesium oxide.

[Figura 5: Micrografias de MEV. (a, b) alumina não modificada, (c) alumina modificada com 5\% de óxido de bário e (d) alumina modificada com 5\% de óxido de cálcio e (e) alumina modificada com 5\% de óxido de magnésio.] 
layers of the alumina react with barium oxide.

The unmodified alumina (raw material) shows a surface area of $62.70 \mathrm{~m}^{2} / \mathrm{g}$. After a heat treatment at $700{ }^{\circ} \mathrm{C}$ for $2 \mathrm{~h}$, its surface area decreases to $58.20 \mathrm{~m}^{2} / \mathrm{g}$ (Table I). Commonly, increasing the heat treatment temperature, occurs the formation of a sintered alumina phase, such as $\alpha-\mathrm{Al}_{2} \mathrm{O}_{3}$, with the consequent grain growth; and this process progressively reduces the surface area of the material. This behavior was also observed for the BJH cumulative desorption surface area of pores, see Table I. A negative volume and area of micropores can be an indication of the absence of micropores in the samples [15]. The sample of alumina modified with barium oxide was the one that presented the greatest modifications in surface and pore structures, as compared with the unmodified alumina sample. Probably, this is due the formation of a new crystalline phase of barium aluminate on the surface of alumina.

Fig. 4 shows the surface and pore properties of the samples analyzed by nitrogen adsorption-desorption measurements. Fig. 4 (a) shows that all isotherms behave similarly, as typical type IV sorption with $\mathrm{H} 2$ hysteresis loop. This behavior is characteristic of mesoporous structures $(2-50 \mathrm{~nm})$. The pore size distribution obtained by the $\mathrm{BJH}$ method for the samples shows narrow monomodal distributions in the region between 2 and $50 \mathrm{~nm}$, see Fig. 4(b). Significant changes were not observed in the average pore diameters of the samples, which were kept at around $9 \mathrm{~nm}$. These results suggest that uniform pore structures were maintained even after the modification of the alumina surface.

In Figs. $5 \mathrm{a}-\mathrm{b}$, it can be observed that particles of the commercial alumina show bimodal grain size distribution. The coarser part of the sample is formed by agglomerates with average size of $40 \mu \mathrm{m}$. In these agglomerates there are large grains with average size about $10 \mu \mathrm{m}$, see Fig. 5 a. These large particles probably present corundum phase [16]. Fig. $5 \mathrm{~b}$ displays the finer part of the commercial alumina, which shows an average size of about $200 \mathrm{~nm}$. These fine particles could be related to aluminum oxide (monoclinic) phase.

Fig. $5 \mathrm{c}$ shows the morphology of the sample of alumina modified with barium oxide, displaying particles of about $1 \mu \mathrm{m}$, it can be noticed that such morphology is similar to the mesocrystal structure reported [17]. In the particle enlarged, the aluminate phase, displaying the stoichiometry $\mathrm{BaAl}_{9.2} \mathrm{O}_{14.8}$, is clearly observed on the surface of the alumina. The aluminate phase is formed by agglomerated nanometric particles with $50 \mathrm{~nm}$ of average size. In the SEM micrographs of the samples of alumina modified with calcium oxide, Fig. 5d, and magnesium oxide, Fig. 5e, new phases were observed on the surface of the alumina particles. These phases were not observed by XRD analysis, and then these compounds formed on the surface present non-crystalline phases. In the scientific literature, various vitreous phases of calcium and magnesium aluminates are reported [18]. Fig. $5 \mathrm{~d}$ shows small areas of the new non-crystalline phase on the alumina surface for the samples of alumina modified with calcium oxide. These small areas present an average size smaller than $50 \mathrm{~nm}$. In Fig. 5e, representing the sample of alumina modified with magnesium oxide, nanometric flakelike structures can be observed on the surface of alumina. These flakes presented an average thickness of around 30 $\mathrm{nm}$ and average length of about $500 \mathrm{~nm}$.

Fig. 6 shows that the catalysts based on alumina modified with alkaline earth metal oxides were efficient for transesterification reaction of babassu oil. No significant reaction was noticed with unmodified alumina. It can be seen in Fig. 6 that the catalyst with 5\% magnesium oxide presented the best methyl ester yield. This is due to the fact that magnesium oxide addition leads to a number of alkaline sites higher than does the addition of calcium and barium oxides [19].

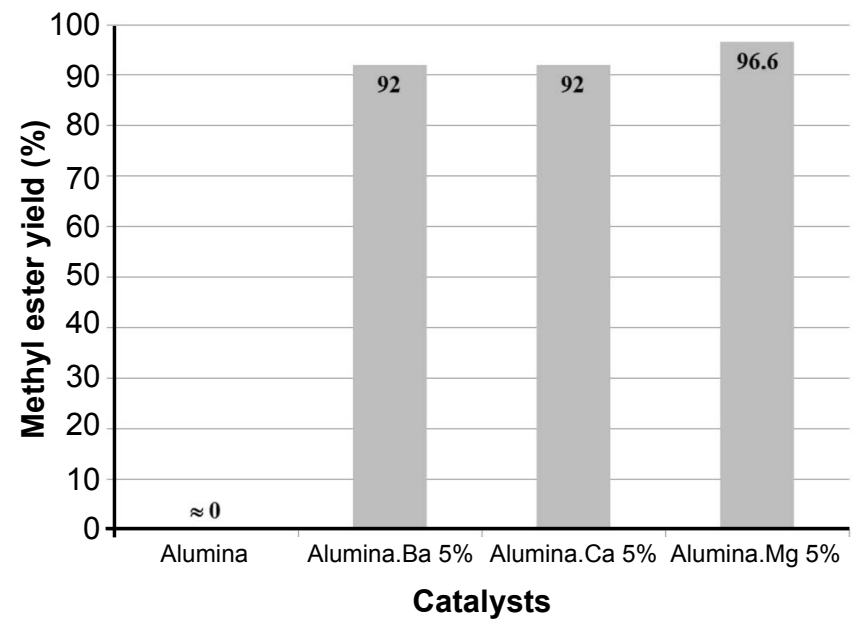

Figure 6: Methyl esters yields obtained for the transesterification of babassu oil using alumina modified with alkaline earth metal oxides as catalysts.

[Figura 6: Rendimentos de ésteres metílicos obtidos para a transesterificação do óleo de babaçu usando alumina modificada com óxidos de metais alcalino-terrosos como catalisadores.]

\section{CONCLUSIONS}

This work describes the synthesis, by the polymeric precursor method, and the properties of surface modifications of alumina with alkaline earth metal oxides. The results suggest that bulk alumina support was not modified in the process; only the surface layers of alumina reacted with alkaline earth metal oxides. The formation of the barium aluminate crystalline phase on the alumina surface is an indicative of the success of this new route for obtaining this kind of material. The isotherms obtained for all samples by nitrogen adsorption-desorption measurements present the same behavior, as typical type IV sorption with $\mathrm{H} 2$ hysteresis loop, which is characteristic of mesoporous structures (2$50 \mathrm{~nm}$ ). The results suggest that uniform pore structures were maintained even after the modification of the alumina surface. Alumina modified with alkaline earth metal oxides ( $\mathrm{Ba}, \mathrm{Ca}$ and $\mathrm{Mg}$ ) was shown to be efficient heterogeneous catalysts for the transesterification reaction of babassu oil. 


\section{ACKNOWLEDGEMENTS}

The authors acknowledge the Brazilian financing agencies: FAPEMA, FAPESP, CNPq, CAPES and FINEP.

\section{REFERENCES}

[1] D. M. Ibrahim, Y. M. Abu-Ayana, Mater. Chem. Phys. 113, 2-3 (2009) 579.

[2] W. Zhou, X. Niu, G. Min, Z. Song, J. Zhang, Y. Liu, X. Li, J. Zhang, S. Feng, Microelectr. Eng. 86, 12 (2009) 2375. [3] Q. He, D. Zheng, S. Hu, Microchim. Acta 164, 3-4 (2009) 459.

[4] E. Besenyei, G. Katona, P. Arato, A. Kele, Supercond. Sci. Technol. 2, 4 (1989) 220.

[5] Y. Mao, B. M. Fung, J. Chromatogr. A 790, 1-2 (1997) 9.

[6] G. Di Carlo, L. F. Liotta, G. Pantaleo, A. M. Venezia, G. Deganello, Top. Catal. 52 (2009) 1826.

[7] M. R. Othman, S. C. Tan, S. Bhatia, Micropor. Mesopor. Mater. 121, 1-3 (2009) 138.

[8] K. Pansanga, N. Lohitharn, A. C. Y. Chien, E. Lotero, J. Panpranot, P. Praserthdama, J. G. Goodwin Jr., Appl. Catal. A 332, 1 (2007) 130.
[9] Y. W. Chen, H. Y. Chen, W. F. Lin, React. Kinet. Catal. Lett. 65, 1 (1998) 83.

[10] A. P. Maciel, E. R. Leite, E. Longo, J. A. Varela, Cerâmica 51, 317 (2005) 52.

[11] I. L. V. Rosa, A. P. Maciel, E. Longo, E. R. Leite, J. A. Varela, Mater. Res. Bull. 4110 (2006) 1791.

[12] L. Perier-Camby, G. Thomas, Solid State Ionics 63-65 (1993) 128.

[13] L. Perier-Camby, G. Thomas, Solid State Ionics 93, 3-4 (1997) 315.

[14] G. Groppi, C. Cristiani, P. Forzatti, M. Bellotto, J. Mater. Sci. 29, 13 (1994) 3441.

[15] J. R. Matos, L. P. Mercuri, M. Kruk, M. Jaroniec, Chem. Mater. 13, 5 (2001) 1726.

[16] Z. Li, Z. Li, A. Zhang, Y. Zhu, J. Alloy. Compd. 476, 1-2 (2009) 276.

[17] X. Lu, X. Li, F. Chen, C. Ni, Z. Chen, J. Alloy. Compd. 476, 1-2 (2009) 958.

[18] L. A. Díaz, R. Torrecillas, A. H. De Aza, P. Pena, S. De Aza, J. Eur. Ceram. Soc. 25, 9 (2005) 1499.

[19] K. Tanabe, Y. Fukuda, React. Kinet. Catal. Lett. 1, 1 (1974) 21.

(Rec. 28/05/2013, Ac. 12/10/2013) 